\title{
Cricket Farming for Animal Protein as Profitable Business for Small Farmers in Indonesia
}

\author{
Asnath Maria Fuah, Hotnida Caroline Herawati Siregar and Yuni Cahya Endrawati \\ Department of Animal Production and Technology, Faculty of Animal Science, Bogor Agricultural University, Agatis Street, Bogor \\ 16680, Indonesia
}

\begin{abstract}
Cricket is widely recognized in Indonesia especially in Java island, and commonly kept by village farmers for food and feed. In general, crickets has very short life cycle (60-70 d), with three weeks of laying period and egg production within the range of 200-1,500 eggs/female. The female has capability for multiple mating with several males and therefore produces more fertile eggs. Serial studies including experiments on laboratory and field observation of local crickets had been conducted to evaluate the farming practices and reproductive performance of three local species (Gryllus spp., Gryllus mitratus and Gryllus testaceus) which were given local feeds-Manihot esculenta and Carica papaya leaves. The experiment was conducted in randomized block design with feed as the treatments and species as the block. Cliring crickets (G. mitratus) fed with M. esculenta leaves revealed the highest total egg production (1,478.22 eggs), with daily egg production of 32.85 eggs/d, the longest laying period (45 d), the lowest feed intake $(0.28 \mathrm{~g} / \mathrm{head})$ and feed conversion $(0.93 \mathrm{mg} / \mathrm{egg})$, compared to Cendawang crickets (G. testaceus) and Gryllus spp.. The revenue and cost $(\mathrm{R} / \mathrm{C})$ ratio was 1.4 , indicating that small scale cricket enterprise could offer significant profit and could be chosen as an alternative activities for earning regular income.
\end{abstract}

Key words: Gryllus, local feed, performance, economic potential.

\section{Introduction}

The increase in human population inevitably triggers the increase in food demand. Although a variety of food sources have been intensively developed, but protein sources are still lacking. Different efforts have been carried out to come up with new protein sources with high productivity both from animal and plant origins. One of the alternative sources is an insect called cricket. Cricket has been widely known in Indonesia and is usually sold in local markets as pet feed. However, in a number of Asian countries, cricket is consumed as food, since this insect is believed to contain high protein. In fact, the protein content of cricket can reach $60 \%$ [1]. In Indonesia, there are about 123 species of crickets that have been identified, two of which $G$. testaceus (Cendawang cricket) and G. mitratus (Cliring cricket)

Corresponding author: Asnath Maria Fuah, Ph.D., research fields: production and technology of prospective animal, especially insect. E-mail: asnath.fuah@gmail.com. have been considered the best for farming because of large body size and high productivity.

Cricket has a short life cycle $(60-70 \mathrm{~d})$. The female is capable to produce as many as $200-1,500$ eggs/female for three weeks [2]. Fertile eggs will hatch after 10-12 $\mathrm{d}$ of oviposition [3, 4]. Cricket belongs to phytophagous insects (plant eaters) [5], and some of the feed choices are vegetables, foliage and fruits that contain lots of water, papaya and cassava leaves, which are widely available around the community (easily obtained) and can grow easily in all seasons. Devendra [6] reported that cassava leaves had a protein content of $15.8 \%-25 \%$. Mansy [7] also stated that the combination of concentrate with cassava leaves fed to local crickets was able to ensure high productivity. Papaya leaves contain vitamins A, B, C, calcium, energy, protein, carbohydrate and phosphor. The papain enzyme in papaya leaves has an enzymatic substance in form of catalyst power to break down and reduce protein [8].

Breeding and raising of crickets may become 
efficient, because it does not need big capital, and feeds such as papaya and cassava leaves are easily obtained. So cricket farming as a business can be successfully done by small farmers. The cricket demand for food and feed can improve the welfare of cricket farmers. Therefore, any research related to locally-feed resources, including the leaves of cassava and papaya to improve cricket productivity and economic potential, is required to be carried out to evaluate the potential benefits of the insect to human needs. This study aimed to determine the effects of local feeds (cassava leaves and papaya) on the cricket productivity, so that small cricket farmers may benefit from it.

\section{Materials and Methods}

\subsection{Materials}

This study was conducted in the Non-Ruminant and Prospective Animal Laboratory, Faculty of Animal Husbandry, Bogor Agricultural University, Indonesia. It consisted of two phases: (1) the first phase was to evaluate the reproductive performance of crickets which were fed on different feeds; (2) the second phase was to analyze the economic potential of cricket business undertaken by farmers in Rangkapan Jaya Baru village, Pancoran Mas sub-district, Depok city, Indonesia.

The research used Gryllus spp. (Gs), Cliring crickets (G. miratus $/ \mathrm{Gm})$ and Cendawang crickets $(G$. testaceus/Gt), and each consisted of 20 males and 100 females. The size of the enlargement cage was $60 \times 45$ $\times 30 \mathrm{~cm}$, and the box treatment was $25 \times 25 \times 20 \mathrm{~cm}$. A sprayer, electric scales and thermo-hygrometer were also used in this study. The feeds given included a concentrate of broiler chicken feed with a protein content of $20 \%-22 \%$ and forage such as cassava (Manihot esculenta/Me) and papaya (Carica papaya/Cp) leaves. Concentrate was given every five days, while forage every two days in ad libitum.

\subsection{Procedures and Data Analysis}

\subsubsection{Phase I}

Eggs produced by the parent of each cricket's species which raised in an enlargement cage were harvested and incubated, and then the nymphs were raised until 57 days old. The sample crickets were taken randomly and given two types of feed: (1) a combination of concentrate and cassava leaves; (2) a combination of concentrate and papaya leaves. Treatments in the first phase is presented in Table 1.

Each treatment had 10 replications and each replication consisted of one male and five females, which were raised in one raising box. The mating period lasted for about $10 \mathrm{~d}$.

The variables observed in phase I were:

(1) Total feed, forage or concentrate intake (TFI) was feed, forage or concentrate intake of cricket in certain treatment during laying period, calculated as Eq. (1):

$$
\mathrm{TFI}(\mathrm{g} / \mathrm{head})=\sum_{t=1}^{n}(\mathrm{IF}-\mathrm{RF}) \times \mathrm{DM}
$$

where, $t=$ laying period; IF = initial feed, forage or concentrate given; $\mathrm{RF}=$ residual feed, forage or concentrate; $\mathrm{DM}=$ dry matter.

(2) Daily feed or forage or concentrate intake (DFI) was daily feed or forage or concentrate intake of cricket in certain treatment during laying period, calculated as Eq. (2):

Table 1 Crickets species and type of feed in phase I.

\begin{tabular}{lcc}
\hline \multirow{2}{*}{ Cricket species (block) } & \multicolumn{2}{c}{ Type of feed (treatments) } \\
\cline { 2 - 3 } & $\begin{array}{c}\text { Concentrate + cassava leaves } \\
(\mathrm{Me})\end{array}$ & $\begin{array}{c}\text { Concentrate + papaya leaves } \\
(\mathrm{Cp})\end{array}$ \\
\hline Gryllus spp. $(\mathrm{Gs})$ & $\mathrm{Gs}-\mathrm{Me}$ & $\mathrm{Gs}-\mathrm{Cp}$ \\
G. mitratus $(\mathrm{Gm})$ & $\mathrm{Gm}-\mathrm{Me}$ & $\mathrm{Gm}-\mathrm{Cp}$ \\
G. testaceus $(\mathrm{Gt})$ & $\mathrm{Gt}-\mathrm{Me}$ & $\mathrm{Gt}-\mathrm{Cp}$ \\
\hline
\end{tabular}




$$
\operatorname{DFI}(\mathrm{g} / \mathrm{head} / \mathrm{d})=\frac{\text { TFI in laying period } t}{\text { total days of laying period } t}
$$
where, TFI $=$ total feed, forage or concentrate intake.

(3) Total egg production (TEG) was total number of eggs produced by female of certain treatment during laying period, calculated as Eq. (3):

$$
\begin{aligned}
& \text { TEG (number of eggs/female) }= \\
& \sum_{t}^{n} \frac{\text { number of harvested eggs }}{\text { number of female }}
\end{aligned}
$$

where, $t=$ laying period.

(4) Daily egg production (DEG) was the number of eggs produced every day in certain treatment during laying period, calculated as Eq. (4):

DEG (number of eggs/female/d) = total egg production in laying period $t$

total days of laying period $t$

(5) Feed conversion (mg/eggs) was amount of feed needed to produce one egg, calculated as Eq. (5):

Feed conversion ${ }_{t}=\frac{\text { total feed intake }_{t}}{\text { total egg production } t}$

(6) Mortality (\%) was the percentage of dead crickets from the total numbers of crickets during laying period, calculated as Eq. (6):

$$
\text { Mortality }=\frac{\text { numbers of dead crickets }}{\text { total numbers of initial sample }} \times 100
$$

The design used was a randomized block design with feed as the treatment and species as the block. The mathematical model [9] was as Eq. (7):

$$
Y_{i j k}=\mu+\tau_{i}+\beta_{j}+\varepsilon_{i j k}
$$

where, $Y_{i j k}=$ observation value at replication $k$ of feed $i$ and species $j$;

$\mu=$ general average;

$\tau_{i}=$ effect of feed combination $i$;

$\beta_{j}=$ effect of species $\mathrm{j}$;

$\varepsilon_{i j k}=$ experimental error at replication $k$ of feed $i$ and species $j$;

$i=$ feed combination, (1) concentrate and cassava leaves and (2) concentrate and papaya leaves;

$j=$ species, (1) Gryllus spp., (2) G. mitratus and (3) G. testacius; $k=$ replication $(k=1,2, \ldots ., 10)$.

The data were analyzed using analysis of variance (ANOVA) at $\alpha=0.01$ to examine the effect of feed on reproductive performance of three cricket species, including feed intake, feed conversion, egg production and mortality.

\subsubsection{Phase II}

In the second phase of the study, survey and exploration methods were used to obtain primary and secondary data. The primary data were obtained from six cricket farmers, 30 people who lived around cricket farms (within 30-50 m) and 14 cricket collectors. The data were obtained by conducting interviews and observations on the farms. The secondary data were derived from relevant agencies and other research reports.

The variables observed were revenue and $\operatorname{cost}(\mathrm{R} / \mathrm{C})$ ratio and trends of demand. Analysis of $\mathrm{R} / \mathrm{C}$ ratio was conducted to determine whether the cricket business was profitable or not. $\mathrm{R} / \mathrm{C}$ ratio was calculated by the Eq. (8):

$$
\frac{R}{C}=\frac{\text { total farming income }}{\text { total farming cost }}
$$

where, $R / C>1$ means the business was profitable;

$R / C<1$ means the business was not profitable;

$R / C=1$ means the business gained no profit, but did not have a loss either (break even point).

Trends of criket demand were analyzed by time series model in a linear regression, with the following Eq. (9):

$$
Y=a+b X
$$

where, $Y=$ demand for crickets (head);

$X=$ time variable;

$a$ and $b=$ parameter or regression coefficient.

\section{Results and Discussion}

\subsection{Environmental Condition}

Temperature and humidity were measured to determine the environmental conditions during the study. The results showed that the average 
temperature in the raising box was $28.64{ }^{\circ} \mathrm{C}$ with an average humidity of $63.53 \%$. The temperature was still in the optimum range for crickets, which were about $20-32{ }^{\circ} \mathrm{C}$, but the humidity was slightly lower than the optimum range. The growth and productivity of crickets were strongly influenced by the temperature and humidity of the environment, so that these two factors should be given special attention in breeding and raising crickets. In Indonesia, according to Sukarno [10], crickets generally live well in areas with temperatures between $20-32{ }^{\circ} \mathrm{C}$ with a humidity of $65 \%-80 \%$.

\subsection{Reproductive Performance}

\subsubsection{Feed Intake}

The results of ANOVA showed that the feed combination had a very significant effect on total and daily feed intake of Cendawang crickets (Gt), but not of the other two species, i.e., higher when given cassava leaves (Gt-Me) than papaya (Gt-Cp) (Fig. 1).

Cendawang cricket had a bigger body size compared to the other two spesies and thus it was more capable to eat more feed. Cassava leaves texture is softer than papaya, so cutting and chewing it needed less energy, hence the higher preferences to consume more cassava leaves [11].

The lowest feed intakeof Cliring crickets (Gm-Me and $\mathrm{Gm}-\mathrm{Cp}$ ) seemed also to be related to its body size. Among the three species, Cliring cricket has the smallest body size.

Fig. 2 showed that the feed intake of Cendawang crickets (Gt-Me and Gt-Cp) was high but varies during the laying period, while the feed intake of Gryllus spp. (Gs-Me and Gs-Cp) and Cliring crickets (Gm-Me and Gm-Cp) were low but stable. Gryllus spp. crickets had a shorter laying period, because all of the samples were died before days 30, otherwise Cliring crickets still lived up to days 40 so its laying period was the longest among the three species. According to Widiyaningrum [12], this result might be related with cricket species, types of feed given to the insect and the feed palatability.

Feed is one of the major production cost components in raising activities. Therefore, this study provided valuable information about feeding behavior during reproduction phase that could be apllied in crickets farming. However, this behavior should be supported by the female productivity.

\subsubsection{Egg Production}

The treatment of feed had a very significant effect $(P<0.01)$ on egg production. All crickets species, which received feed combination of concentrate and cassava leaves (Gs-Me, Gm-Me, and Gt-Me), had the highest egg production (Fig. 3). This is presumably

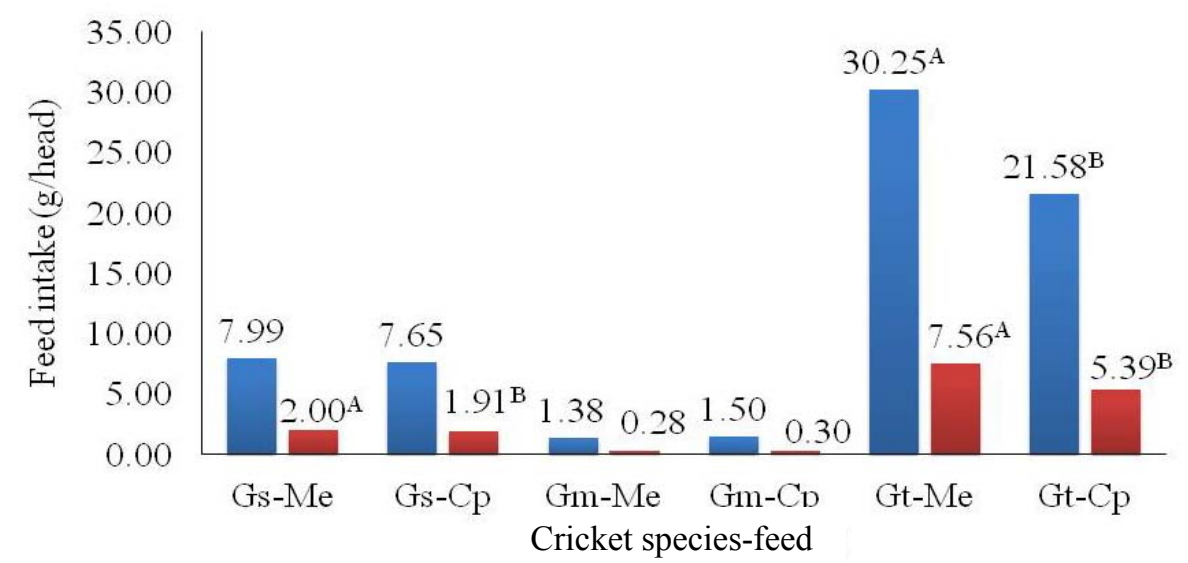

Fig. 1 Total and daily feed intake of three species of cricket fed on combination of concentrate and cassava or papaya leaves.

- Total feed intake; A, B: different superscript in the same species means very significantly diferent total feed intake $(P<0.01)$;

- Daily feed intake; A, B: different superscript in the same species means very significantly diferent daily feed intake $(P<0.01)$. 


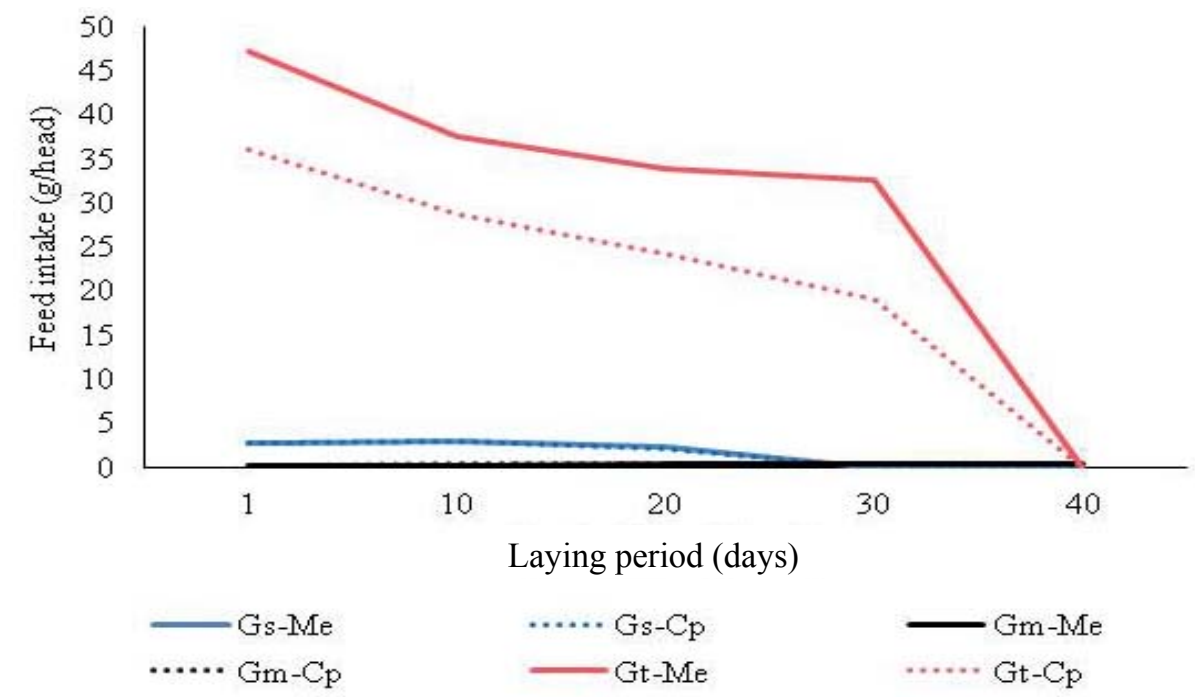

Fig. 2 Feed intake of three species of crickets fed on combination of concentrate and cassava or papaya leaves during the laying period.

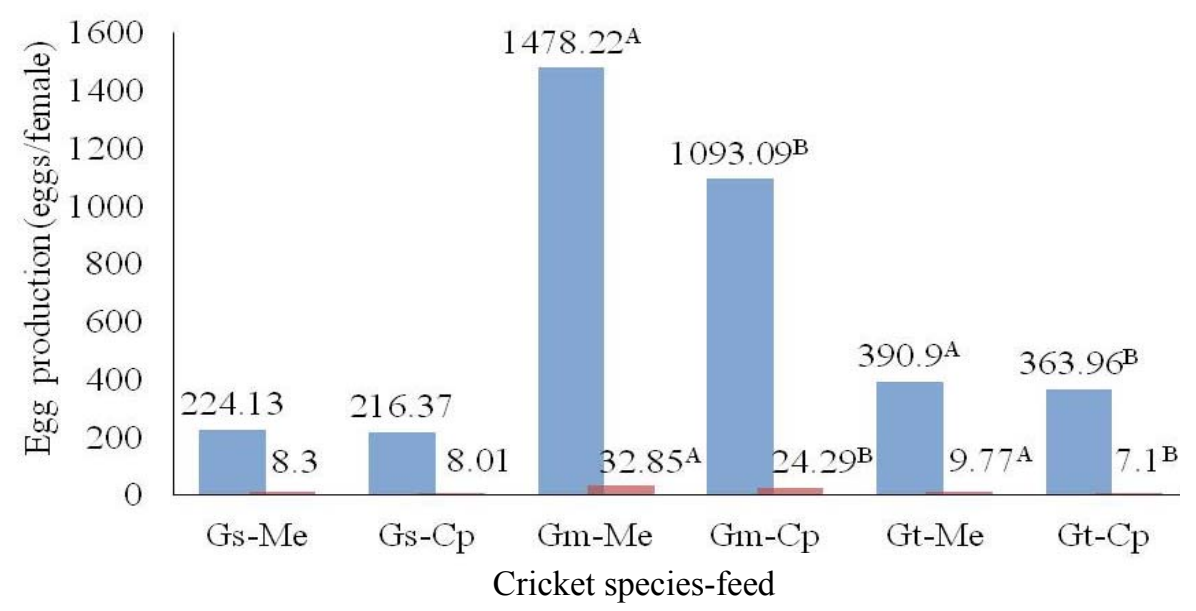

Fig. 3 Total and daily egg production of three species of crickets fed on combination of concentrate and cassava or papaya leaves.

- Total egg production; A, B: different superscript in the same species means very significantly diferent total egg production $(P<0.01)$;

- Daily egg production; A, B: different superscript in the same species means very significantly diferent daily egg production $(P<0.01)$.

because the protein content of cassava leaves is higher than papaya leaves $(22.8 \%-10 \%)$. This also indicated that crickets in the reproduvtive phase need more protein to increase egg production. Megindo et al. [13] suggested that the minimum requirement of protein in criket feed was 19\%. This study revealed that the number of eggs produced by Cliring crickets fed on cassava leaves (Gm-Me: 1,478 eggs/female) was larger than that in report of Ref. [1] (1,200 eggs/female).

Cliring crickets' highest total and daily egg production when given both type of feeds (Gm-Me and Gm-Cp) was not consistent with its lowest feed intake (Fig. 1) due to the highest female productivity and longest laying period (Fig. 4). Laying period is an important factor for farmers. The longer the laying period is, the more income the farmers will earn, because the number of eggs produced will increase. Cliring crickets had the longest laying period compared to Cendawang crickets and Gryllus spp., i.e., 45, 40 and $27 \mathrm{~d}$, respectively. Moreover, during the laying period, the egg production of this species remained high (Fig. 4). Most cricket species have high 
production of eggs only in the beginning of a laying period. This is in line with the research result in Ref. [11], which showed that the highest average egg production was reached by G. mitratus (Cliring crickets: 2,576 eggs/female).

Khaliq et al. [14] showed a negative correlation between insect body size and diet composition, i.e., smaller insect forage for higher feed quality. Furthermore, Knapp and Unhavá [15] showed that the bigger the insect body size is, the higher its egg production is. The result of these two studies contrast with this study. All species in this study were fed on the same feed and Cliring crickets body size was the smallest; so there was other factor causing high productivity of Cliring crickets, such as feeding strategy. Table 2 showed that different from Gryllus spp. and Cendawang, Cliring crickets consume more leaves to cope with evaporation due to the lower environmental humidity $(63.53 \%)$ than the optimum (65\%-80\%). Water content of the leaves $(14.01 \%$ in cassava leaves and $15.92 \%$ in papaya leaves) was higher than concentrate $(8.33 \%)$.

This feeding strategy sustained high egg productivity of Cliring female. Humidity could affect insect ovulation and rate of fecundity [14]. This result showed the superiority of Cliring in adapting to the environment compared to the other two species, so that it is more widely cultivated.

\subsubsection{Feed Conversion}

The result in Fig. 5 indicated that the lowest feed conversion was shown by Cliring crikets. Feed conversion is an indicator for the animal ability to change feed into growth and production. Small conversion value in this study indicated that Cliring crickets were very efficient in utilizing feed nutrients for its egg production.

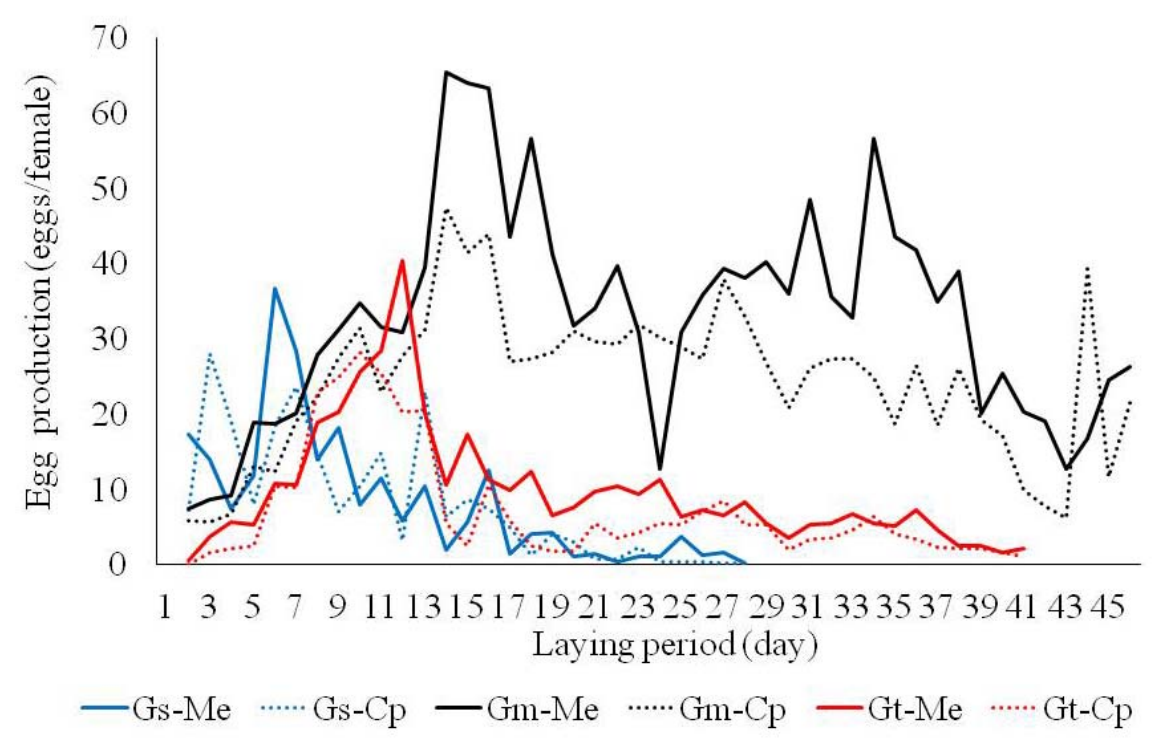

Fig. 4 Egg production of three species of crickets fed on combination of concentrate and cassava or papaya leaves during the laying period.

Table 2 Concentrate and leaves intake of three cricket species during laying period.

\begin{tabular}{|c|c|c|c|c|}
\hline \multirow[t]{2}{*}{ Cricket species } & \multicolumn{2}{|c|}{$\begin{array}{c}\text { Concentrate + cassava leaves } \\
(\mathrm{Me})\end{array}$} & \multicolumn{2}{|c|}{$\begin{array}{c}\text { Concentrate + papaya leaves } \\
(\mathrm{Cp})\end{array}$} \\
\hline & Concentrate & Cassava leaves & Concentrate & Papaya leaves \\
\hline Gryllus spp. (Gs) & 4.53 & 3.46 & 4.56 & 3.09 \\
\hline Cliring (Gm) & 0.34 & 1.04 & 0.33 & 1.17 \\
\hline Cendawang (Gt) & 54.84 & 96.41 & 54.99 & 52.89 \\
\hline
\end{tabular}


Cliring crickets were very effective in the use of feed nutrients, probably because they have a thick exoskeleton structure, which will minimize evaporation of the body liquid, making it efficient in the utilization of water from the feed. Therefore, with relatively lower feed intake compared to other species of crickets, Cliring crickets can produce more eggs.

\subsubsection{Mortality}

The mortality of crickets was influenced by the types of feed and cricket species. Fig. 6 shows that Gryllus spp. had the highest mortality $(P<0.01)$, since the early period of production. Meanwhile, the mortality rate of Cendawang cricket was the lowest compared to the other two species.

Although Gryllus spp. and Cendawang females had a lower mortality in the second week of egg laying period, but both of these species had lain most of their eggs in the first two weeks and thereafter only produce fewer eggs (Fig. 4). These conditions were not favorable for farmers, because the maintenance after two weeks of laying period is a waste of feed, cages and human resources. In contrast, a high mortality

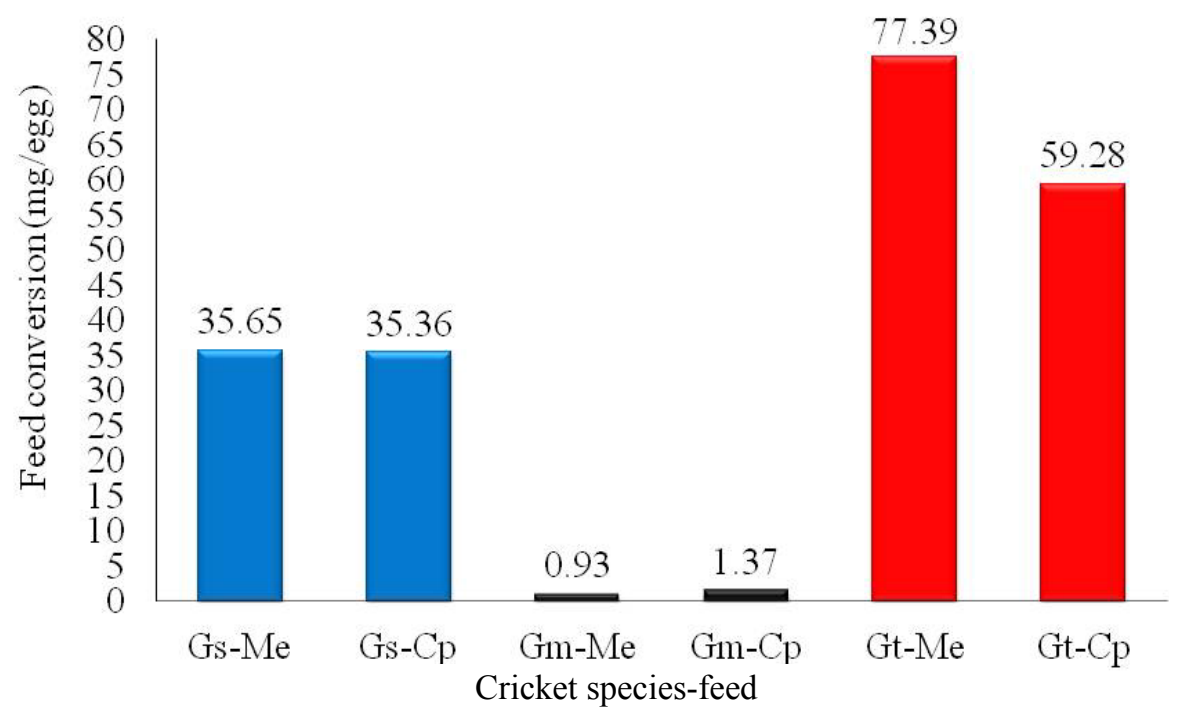

Fig. 5 Feed conversion of three crickets species fed the combination of concentrate and cassava or papaya leaves.

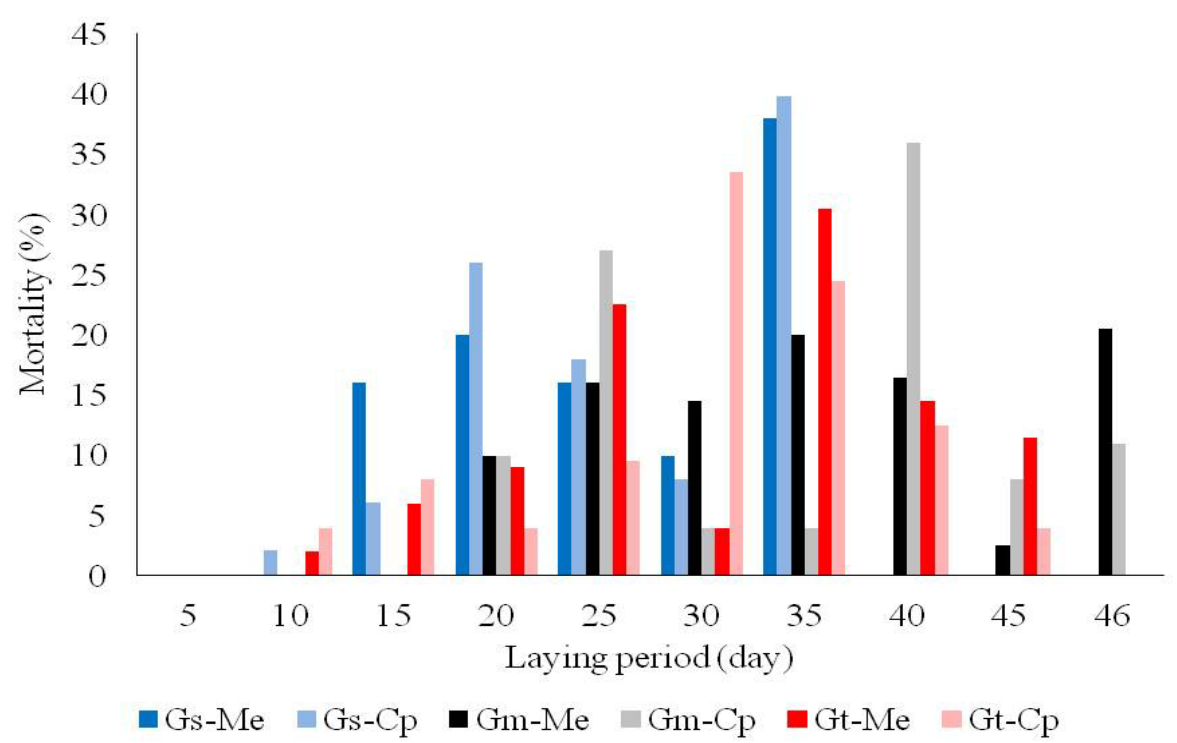

Fig. 6 Mortality rate of three crickets species given combination of concentrate and cassava or papaya leaves during layingperiod. 
rate in the early days of laying period occurs in Cliring females, which had lain most of their eggs. While the remaining females survived longer than the other two species and produced a lot eggs over seven week of laying period. Varied mortality in Cliring female was the expression of the high level of diversity that open the opportunity for genetic improvement through breeding programs.

\subsection{Potential of Cricket Business Development}

The success of a farming business cannot be separated from the quality of its human resources. The characteristics of cricket farmer based on the study were as follow: low education $(66.67 \%$ junior high school and $16.33 \%$ elementary school) with age ranging in 23-56 years. Most of the farmers had 1.5-9 years of experience and they raised cricket as the main job (83.3\%) with scale of 32-100 boxes. Their reasons for raising crickets were having no permanent jobs (unemployed), its easy to do, low investment, rapid payback and low competition.

Cricket farmers usually analyzed the cricket business development and opportunities based on the value of the expenditure and income without taking into account other contributing factors, such as land and labor, which is in general a family asset. Aside from the income component, farmers also predict the potential market through the high demand for crickets.
The total average income from the sales of crickets in Rangkapan Jaya Baru village, Depok, was IDR33,738,435 $(\$ 2,812)$ per year with an average total numbers of 1,526,100 crickets/farmer/year.

In this business, there were cost variables, such as the costs of parent crikets or eggs, feed, labor, transportation and equipment. The average variable cost incurred by farmers was IDR21,615,042 $(\$ 1,801)$ and a fixed cost of IDR2,280,000 (\$190), with labor as the largest component $(61.086 \%$ of the total expenses or IDR14,600,000 or $\$ 1,217)$.

The cricket business income earned in gross margin amounted to IDR12,123,393/year $(\$ 1,010)$. The average net income received by farmers each year was IDR9,837,705 (\$819.8) with an average business scale of 58 boxes/farmer. These production scale were generally still higher than the cricket production in Kenya, which reached $13.75 \mathrm{~kg} /$ month. Assuming that the price of crickets in Indonesia was around IDR 50,000 , the income recived by Kenya cricket farmers was IDR687,500/farmer/month or IDR8,250,000/ farmer/year (\$687.5). The average value of $\mathrm{R} / \mathrm{C}$ ratio calculated from this business was 1.4 , indicating that the criket business was quite feasible. Every single dollar invested in cricket farming business would provide a revenue of IDR1,410 (\$0.12). The result of economic analysis revealed the total sales of crickets by farmers seemed to increase every month, which was

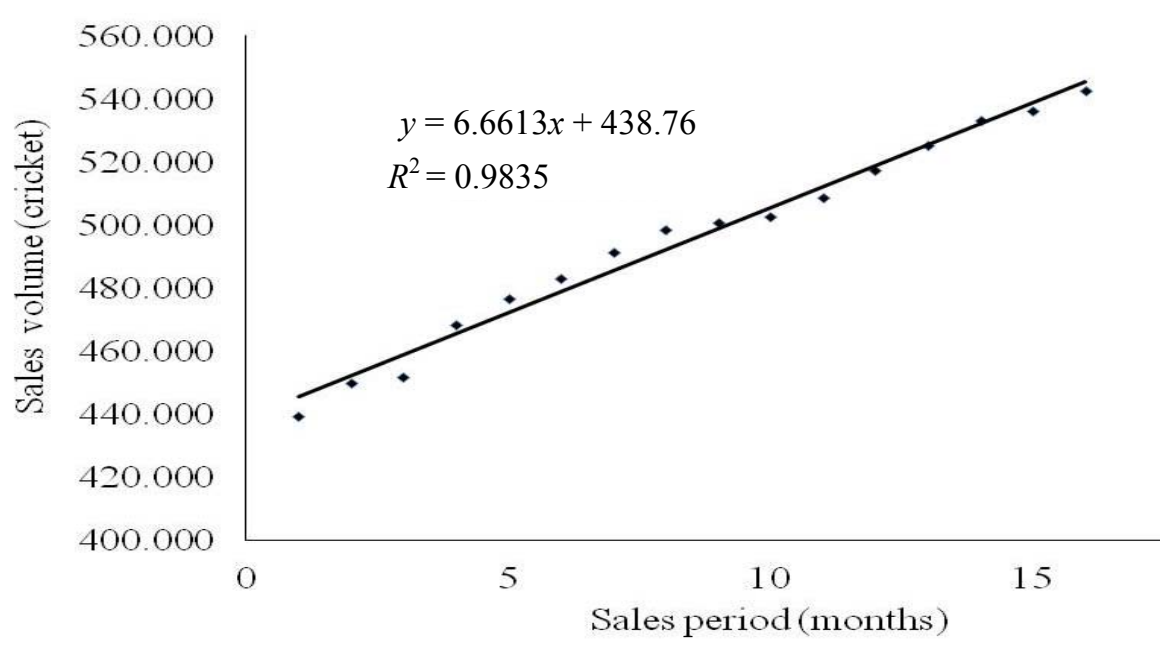

Fig. 7 Sales volume at certain sales period. 
resulted in cash income received by the farmers.

The potential market for crickets was in the form of clondo (nymph) as well as adult crickets (imago). Cricket's nymphs were the most saleable products in the market, and the main consumers were bird keepers. Crickets were also purchased to make herbal medicine (in capsule form), snacks and cricket soil. The trends of demand for cricket can be seen in Fig. 7, which showed that there were potential and opportunity to increase production scale to meet the demand, characterized by the increase of sales volume from month to month.

Until now, oversupply had never occurred in this business, so that opportunities for raising crickets were still wide open. Therefore, efforts to increase production optimally through good management, effective and efficient reproduction and appropriate marketing system are certainly required. Some aspects to be considered in the development of cricket business are feed efficiency, environment, reproduction, mortality and business scale.

\section{Conclusions}

Manihot esculenta leaves increased Cliring crickets (G. mitratus) feed efficiency and egg production than papaya leaves. Cliring cricket raising is a potential business, because it had a high revenue ( $\$ 819.8 /$ year) and $\mathrm{R} / \mathrm{C}$ ratio 1.4 .

\section{References}

[1] Paimin, F. B. 1999. Overcoming Problems in Raising Crickets. Jakarta: Penebar Swadaya Publisher. (in Bahasa)

[2] Patton, R. L. 1978. "Growth and Development Parameters for Acheta domesticus." Annals of the Entomological Society of America 71 (1): 40-2.

[3] Hill, D. S. 1983. Agricultural Insect Pests of the Tropics and Their Control, 2nd ed.. Cambridge, London: Cambridge University Press.

[4] Rosyadi, F. 2001. "Influence of Sex Ratios and the Type of Feed on Reproduction and Feed Consumption of Crickets (Gryllus testaceus)." M.Sc. thesis, Faculty of Animal Husbandry, Bogor Agricultural University, Bogor. (in Bahasa)

[5] Chapman, R. F. 1975. The Insects: Structure and Function. London: Elsevier.

[6] Devendra, C. 1977. "Cassava as Feed for Ruminants in Cassava as Animal Feed." In Proceedings of the University of Guelph Workshop, 107-19.

[7] Mansy, F. 2002. "Performance of Necklace Crickets (Gryllus bimaculatus) Given Combination of Concentrates with Mustard Leaf and Cassava Leaf during the Growth Period." M.Sc. thesis, Faculty of Animal Husbandry, Bogor Agricultural University, Bogor. (in Bahasa)

[8] Kalie, M. B. 1966. Planting Papaya. Jakarta: Penebar Swadaya. (in Bahasa)

[9] Mattjik, A. A., and Sumertajaya, M. 2002. Experimental Design with SAS and Minitab Applications, 2nd ed.. Bogor: IPB Press. (in Bahasa)

[10] Sukarno, H. 1999. Crickets Raising. Yogyakarta: Penerbit Kanisius. (in Bahasa)

[11] Č́ižek, L. 2005. "Diet Composition and Body Size in Insect Herbivores: Why Do Small Species Prefer Young Leaves.” Eur. J. Entomol. 102: 675-81.

[12] Widiyaningrum, P. 2009. "Growth of Three Local Crickets Cultivated on Different Stocking Density and Kinds of Feed." Berk. Penel. Hayati 14: 173-7.

[13] Caparros-Megido, R., Albi, T., Nieus, C., Blecker, C., Danthine, S., Paul, A., Haubruge, E., and Francis, F. 2014. "Optimization of Cricket Breeding Production System for Human Food in Ratanakari Province (Cambodia)." Presented at the International Conference of Insect to Feed the World.

[14] Khaliq, A., Javed, M., Sohail, M., and Sagheer, M. 2014. "Environmental Effects on Insects and Their Population Dynamics." Journal of Entomology and Zoology Studies $2(2): 1-7$.

[15] Knapp, M., and Unhavá, K. 2014. "Body Size and Nutrition Intake Effects on Fecundity and Overwintering Success in Anchomenus dorsalis (Coleoptera: Carabidae)." J. Insect Sci. 14: 240. 